\title{
Genotypic and Phenotypic Characterization of Streptomyces Species Causing Potato Common Scab in Uruguay
}

M. I. Lapaz, Cátedra de Microbiología, Departamento de Biociencias, Facultad de Química (FQ), Universidad de la República, 11800 Montevideo, Uruguay; J. C. Huguet-Tapia, Department of Plant Pathology, Institute of Food and Agricultural Sciences, University of Florida (UF-IFAS), Gainesville 32611 USA; M. I. Siri, Cátedra de Microbiología, Departamento de Biociencias, FQ, Universidad de la República, 11800 Montevideo, Uruguay; E. Verdier, Dirección General de Servicios Agrícolas, Departamento Laboratorios Biológicos, Ministerio de Ganadería Agricultura y Pesca, 12900 Montevideo, Uruguay; R. Loria, Department of Plant Pathology, UF-IFAS, Gainesville 32611 USA; and M. J. Pianzzola, Cátedra de Microbiología, Departamento de Biociencias, FQ, Universidad de la República, 11800 Montevideo, Uruguay

\begin{abstract}
Isolation and characterization of common scab (CS) pathogen Streptomyces spp. from Uruguayan potato tubers and soil samples were done in response to significant economic losses due to CS on potato in autumn 2010. Seventy of the 331 isolates were classified as pathogenic owing to their ability to induce necrosis on tuber disks and stunting of radish seedling. Streptomyces spp. causing CS on potato in Uruguay were found to represent a range of different species by virtue of their diverse morphological and physiological traits as well as rep-PCR, rpoB phylogenetic analysis, and multi-locus sequences analysis. We identified isolates primarily as Streptomyces scabiei, S. acidiscabies, and S. europaeiscabiei. However, some of the pathogenic isolates still remain to be identified at

the species level. This highlights the need for improved methods for discrimination among pathogenic Streptomyces species. The presence of Streptomyces pathogenicity island (PAI) genes was analyzed, including genes encoding for thaxtomin synthetase ( $t x t A, t x t B)$, tomatinase (tomA), and a necrosis protein (nec1). Among the isolates that were pathogenic, $50 \%$ contained the four pathogenicity genes, $33 \%$ had an atypical composition of PAI marker genes, and $17 \%$ did not contain any genes. The absence of the genes reported to be involved in thaxtomin biosynthesis $(t x t A, t x t B)$ was confirmed by whole-genome sequencing of two representative strains of this group. This finding suggests the participation of other virulence factors in plant pathogenicity.
\end{abstract}

Potato common scab (CS) is a widespread disease throughout the world resulting in significant economic losses due to lesions affecting tuber surfaces. The causal agents are soil-inhabiting grampositive bacteria belonging to the genus Streptomyces consisting of more than 650 species (Euzeby 2016; Loria et al. 2006). Streptomyces spp. play a major role in nutrient cycling and some produce antibiotics and other useful metabolites (Chamberlain and Crawford 2000). Despite the extremely high diversity of this genus, only a few species are plant pathogens. Among them, the first-described and best-characterized species, Streptomyces scabiei, seems to be widespread around the world; although several recent reports indicate that it is infrequently found in Europe (Bouchek-Mechiche et al. 2000; Dees et al. 2013; Flores-Gonzalez et al. 2008). Other more geographically limited species are also associated with CS. Among these are: $S$. acidiscabies, isolated from acid soils where S. scabiei is normally suppressed; and $S$. turgidiscabies, first described in Japan (Lambert and Loria 1989a; Miyajima et al. 1998). These species are considered to be newly emerging pathogens (Bignell et al. 2010; Loria et al. 2006). Other Streptomyces spp. that cause CS include: S. europaeiscabiei identified in Europe, Korea, and North America (Bouchek-Mechiche et al. 2000; Song et al. 2004;

Corresponding author: M. J. Pianzzola; E-mail: mpianzzo@fq.edu.uy

The sequences generated in this study for $r p o B$ were deposited as GenBank Accession Numbers: KM504305-KM504332; KM504334; KM504335; KM504337; KM504338; KM504340-KM504344; KM504346-KM504354; KM504357-KM504360; and KM504362-KM504367. For sequences using MLSA: atpD (KU927508-KU927529, KU927531-KU927534, KU927536, and KU927537); recA (KU927540-KU927561, KU927563-KU927566, KU927568, and KU927569); rpoB (KU927572-KU927593, KU927595KU927598, KU927600, and KU927601); $\operatorname{trpB}$ (KU927604-KU927625, KU927627-KU927630, KU927632, and KU927633). The draft genomes of Streptomyces sp. ST1015 and Streptomyces sp. ST1020 were deposited as LXWC00000000 and LXWD00000000, respectively.

Accepted for publication 29 March 2017.

() 2017 The American Phytopathological Society
Wanner 2009); S. stelliscabiei reported in France, the United States, and Germany (Bouchek-Mechiche et al. 2000; Leiminger et al. 2013; Wanner 2006); S. luridiscabiei, S. puniciscabiei, and S. niveiscabiei isolated from Korea (Park et al. 2003); S. caviscabiei reported in Canada (Faucher et al. 1992; Faucher et al. 1995); and S. reticuliscabiei isolated from France and described by Bouchek-Mechiche et al. (2000).

CS pathogenicity is associated with production of the phytotoxic dipeptide thaxtomin $\mathrm{A}$, which induces characteristic symptoms in tubers. The thaxtomin biosynthetic cluster $(t x t)$ is encoded in the chromosomes of $S$. scabiei, $S$. turgidiscabies, and $S$. acidiscabies. Furthermore, the $t x t$ gene cluster is localized in mobile pathogenicity islands (PAIs) (Kers et al. 2005; Huguet-Tapia et al. 2014; Zhang et al. 2016). This suggests that horizontal gene transfer likely plays a role in the acquisition of the txt gene cluster by Streptomyces spp., and consequent potential emergence of new pathogenic Streptomycetes (Bignell et al. 2014; Loria et al. 2006). Some studies have shown that a number of Streptomyces isolates lacking thaxtomin A genes are also CS pathogens (Jordaan and van der Waals 2016; Pánková et al. 2012; Wanner 2004). Bignell et al. (2014) recently described other phytotoxic secondary metabolites that may contribute to CS symptom development. This might explain why isolates without thaxtomin A genes are still pathogenic and produce characteristic symptoms. Genes including necl and tomA are involved in enhancing pathogenicity, although they are not essential for symptom development (Seipke and Loria 2008; Wanner 2009). Necl encodes a protein inducing necrosis in plant tissue, and tomA encodes a virulence factor homologous to tomatinase, an enzyme that belongs to saponinases found in plant pathogenic fungi (Bukhalid et al. 1998; Seipke and Loria 2008).

Identification of Streptomyces isolates is very difficult owing to the numerous species described within the genus. The several sequenced genomes for Streptomyces are also very large, between 8 and $10 \mathrm{MB}$. The size and the high rate of recombination of the Streptomyces genome make species identification difficult (Doroghazi and Buckley 2010; Huguet-Tapia et al. 2016). Classical approaches for identification of Streptomyces spp. involve the evaluation of morphological traits, and microscopic and biochemical techniques, which are time-consuming and laborious. Although these methods contribute 
to strain characterization, they do not allow identification of isolates to the species level. In recent years, development and refinement of molecular methods offers many new possibilities for species identification. These methods include species-specific $16 \mathrm{~S}$ rRNA gene sequencing, species-specific marker PCR methods, detection of pathogenicity determinants, and several DNA fingerprinting techniques (Guo et al. 2008; St-Onge et al. 2008; Wanner 2009). Multi-locus sequence analysis (MLSA) has become particularly relevant to this task. This method consists of phylogenetic analysis of multiple housekeeping genes (Guo et al. 2008) and it provides a good resolution to discriminate Streptomyces spp. (Laskaris et al. 2012; Labeda 2011).

Potato is one of the most important horticultural crops in Uruguay (MGAP and Mercado Modelo 2011). Potato production in 2010, however, experienced unusually high economic losses due to CS, corresponding to losses of $29 \%$ of total potato cultivation. The disease was very aggressive and many tubers showed pitted and raised scab lesions (Lapaz et al. 2012). Uruguayan potato producers have usually imported ca. 30\% of seed tubers used in recent years (MGAP and Mercado Modelo 2011). Plant health regulations allow importation of seed tubers that pass a visual control for CS. This visual control is not rigorous enough to avoid introduction of the causal agent for CS disease, and new strategies to screen for the presence of the pathogen are clearly needed. The aim of the present study was to isolate and characterize Streptomyces spp. from CS lesions on potato tubers and from horticultural field soils in Uruguay. To our knowledge, an exhaustive identification and genetic characterization of Streptomyces spp. causing CS in Uruguay, traditionally a potato-producing country, had not been previously undertaken.

\section{Materials and Methods}

Bacterial strains and culture conditions. Five Streptomyces spp. reference strains representing the most important species associated with potato CS were included for phenotyping and genotyping studies: S. scabiei DSM41658 ${ }^{\mathrm{T}}$ (T, type strain); S. stelliscabiei DSM41803 ${ }^{\mathrm{T}}$; S. europaeiscabiei DSM41802 ${ }^{\mathrm{T}}$; S. acidiscabies DSM41668 ${ }^{\mathrm{T}}$; and S. turgidiscabies DSM $41838^{\mathrm{T}}$. Type strains were purchased from the DSMZ culture collection (Braunschweig, Germany). Additionally, 20 unknown Streptomyces spp. strains were kindly provided by Departamento de Protección Vegetal (Fitopatología), Facultad de Agronomía, Montevideo, Uruguay. These strains were isolated from potato tubers during the severe CS outbreak in 2010. Streptomyces isolates and reference strains were routinely cultured on yeast-malt extract agar (YME) (Shirling and Gottlieb 1966) at $28^{\circ} \mathrm{C}$ and maintained as spore suspensions in $20 \%$ glycerol at $-70^{\circ} \mathrm{C}$.

Isolation of Streptomyces spp. from necrotic lesions on potato tubers. Potato tubers (61 samples) and imported seed potato (13 samples) showing symptoms of CS were obtained from potato growers and farm advisors. Samples were obtained from main potato-growing areas in Uruguay (San José, Canelones, and Rocha) in 2010, 2011, and 2012.

Isolation of Streptomyces spp. from scab lesions was performed using a modified method of Loria et al. (2010). Tubers were washed, surface-sterilized with $1.0 \%$ sodium hypochlorite $(\mathrm{NaOCl})$ for 1 min, and rinsed with sterile distilled water. A portion of lesion was macerated in $2 \mathrm{ml}$ sterile distilled water. Dilutions of macerated tissue were spread on NPPC (nystatin, polymyxin, penicillin, and cycloheximide) water agar (Loria et al. 2010) and incubated at $28^{\circ} \mathrm{C}$ for 10 to 14 days. Colonies characteristic of Streptomyces were transferred onto fresh YME and incubated at $28^{\circ} \mathrm{C}$ for 5 to 7 days. Subsequent transfer to fresh medium was done to obtain pure cultures.

Isolation of Streptomyces spp. from soil. Soil samples were collected from various potato fields in San José, Uruguay. Isolation of Streptomyces spp. from soil was done essentially as described by Loria et al. (2010). Air-dried soil (10 g) was added to $100 \mathrm{ml}$ sterile distilled water, and agitated on a shaker for $10 \mathrm{~min}$. Five successive tenfold dilutions of the soil suspension were made using sterile water and $0.1 \mathrm{ml}$ of the three most dilute suspensions were spread uniformly on NPPC water agar. Plates were incubated at $28^{\circ} \mathrm{C}$ for 7 to 10 days and characteristic powdery Streptomyces colonies were transferred to fresh medium. Pure cultures were obtained through repeated culturing of single colonies on YME medium.

Pathogenicity tests. Pathogenicity was tested on tuber slices as described previously by Loria et al. (1995). Cultures of test strains were grown on YME agar medium for 5 to 7 days at $28^{\circ} \mathrm{C}$, and agar plugs from the sporulating colonies were transferred onto disks of excised tuber tissue. Disks were incubated at $28^{\circ} \mathrm{C}$ in the dark and evaluated for the presence of necrosis after 5 days.

In addition, pathogenicity was tested using a radish-seedling bioassay as described previously by Fyans et al. (2016), with some modifications. Streptomyces isolates were cultured in $5 \mathrm{ml}$ of TSB medium on a shaker at $150 \mathrm{rpm}$ for 2 to 3 days at $28^{\circ} \mathrm{C}$. For both tuber slice and radish pathogenicity testing, S. scabiei DSM41658 was included as positive control and sterile water was used as negative control. The pathogenicity tests were done two times for each isolate.

Morphological and physiological characterization of Streptomyces isolates. Morphological and physiological characterization was performed according to the International Streptomyces Project (ISP) (Loria et al. 2010; Shirling and Gottlieb 1966). YME (ISP2) agar was used to assess colony and spore color. Tyrosine agar (ISP7) was used to determine production of melanin. Water agar cultures were used to determine spore-chain type by direct microscopic examination. Carbon utilization medium (ISP9) was used to assess utilization of raffinose. Utilization of D-glucose was also evaluated as positive control of the assay. Carbon source solutions were sterilized by filtration and added to autoclaved ISP9 medium to $1 \%$ final concentration (w/v). Plates were incubated at $28^{\circ} \mathrm{C}$ for up to 10 days.

DNA isolation. Genomic DNA from Streptomyces isolates was extracted according to Sambrook and Russell (2001). The quantity of extracted DNA was measured by Nanodrop ND-100 (Nanodrop Technologies, Stone, UK) and final DNA concentrations were adjusted to $50 \mathrm{ng} / \mu \mathrm{l}$ (by dilution) and stored at $-20^{\circ} \mathrm{C}$ before use.

PAI marker genes. Genomic DNA from reference strains and Streptomyces spp. isolates was analyzed by PCR for the presence of genes characteristic of the $S$. turgidiscabies PAI as described by Kers et al. (2005). Amplifications were performed using specific primer pairs: TxtAB1/TxtAB2 (Wanner 2006) and TxtA1/TxtA2 for the $t x t A$ and $t x t B$ genes (Wanner 2004); Tom3/Tom4 for the tom $A$ gene (Wanner 2006); and Nf/Nr for the necl gene (Bukhalid et al. 1998) (Table 1).

PCR analyses were done in $25 \mu$ l containing $1 \times$ Buffer, 1.0 to $2.0 \mathrm{mM} \mathrm{MgCl} 2$ (Wanner 2006), $200 \mu \mathrm{M}$ each dNTP, $12.5 \mathrm{pmol}$ each primer, 1.0 U of Taq DNA polymerase (recombinant) (Thermo Scientific, Carlsbad, CA), and 50 ng of DNA template. The time and temperature conditions for PCRs were done as described by Wanner (2006). Amplified DNA fragments were separated on $1.5 \%$ agarose gel and analyzed after staining with ethidium bromide.

Genome sequencing and analysis. Whole-genome sequencing of strains ST1015 and ST1020 was performed with the illumina MiSeq platform. We obtained around 20 million 100-bp paired-end reads for each genome. These produce around $100 \times$ coverage. Reads were assembled using Spades 3.5 software (Bankevich et al. 2012). Resulting contigs were annotated using prokka annotation pipeline (Seemann 2014). The contigs were used as a nucleotide sequence database for BLAST searching and the sequences of the virulent factors were used as queries.

Genotyping using rep-PCR. Genetic diversity of pathogenic Streptomyces isolated in Uruguay was determined by fingerprinting techniques rep-PCR (BOX and ERIC-PCR), using primers BOXA1R and ERIC2/ERIC1R, respectively (Louws et al. 1995) (Table 1). The analysis was done with 70 pathogenic isolates, five reference Streptomyces strains (S. acidiscabies DSM41668, S. scabiei DSM41658, S. turgidiscabies DSM 41838, S. europaeiscabiei DSM 41802, and S. stellescabiei DSM 41803) and Ralstonia solanacearum strain UY031 (Siri et al. 2011) as outgroups.

PCR reactions were performed in $25 \mu \mathrm{l}$ containing $1 \times$ Buffer, $6 \mathrm{mM}$ of $\mathrm{MgCl}_{2}, 200 \mu \mathrm{M}$ of dNTP, $25 \mathrm{pmol}$ of each primer, $10 \%$ v/v dimethylsulfoxide (DMSO), $2.0 \mathrm{U}$ of Taq polymerase (recombinant) (Thermo Scientific) and 25 to $140 \mathrm{ng}$ of DNA template.

The amplification cycle conditions were based on Clark et al. (1998) with some modifications, with an initial denaturation step at 
$95^{\circ} \mathrm{C}$ for $5 \mathrm{~min}$; followed by 40 cycles of denaturation at $95^{\circ} \mathrm{C}$ for $1 \mathrm{~min}$, annealing at $50^{\circ} \mathrm{C}$ for $1 \mathrm{~min}$, and extension at $65^{\circ} \mathrm{C}$ for $4 \mathrm{~min}$; and a final extension step at $65^{\circ} \mathrm{C}$ for $10 \mathrm{~min}$. The resulting products were analyzed by electrophoresis using $2 \%(\mathrm{w} / \mathrm{v})$ agarose gels with $0.5 \mu \mathrm{g} / \mathrm{ml}$ ethidium bromide and photographed under UV light. Gel images were analyzed with the software GelCompar 4.2 (Kortrijk, Belgium). The differences between the patterns generated were established by the presence (1) or absence (0) of an amplification product. A similarity matrix was constructed from the binary data with Dice's coefficients and dendogram was generated with UPGMA (Unweighted Pair-Group Method using arithmetic Average) clustering algorithm. Data from ERIC and BOX-PCR were combined for strain comparisons.

Analysis of the rpoB gene. RNA polymerase beta subunit (rpoB) gene was amplified by PCR using primer pair SRPOF1/SRPOR1 (Kim et al. 2004) (Table 1). The rpoB amplifications were done in $25 \mu \mathrm{l}$ containing $1 \times$ Buffer, $1.5 \mathrm{mM} \mathrm{MgCl} 2,250 \mu \mathrm{M}$ each dNTP, 12.5 pmol each primer, $1.25 \mathrm{U}$ of Taq DNA polymerase (recombinant) (Thermo Scientific), $50 \mathrm{ng}$ of DNA template. The amplification cycle conditions were based on Kim et al. (2004) with some modifications, using an initial denaturation step at $95^{\circ} \mathrm{C}$ for $3 \mathrm{~min}$ and an annealing temperature of $56^{\circ} \mathrm{C}$. Amplified DNA fragments were separated on $1.5 \%$ agarose gel and visualized with ethidium bromide under UV light.

Multi locus sequence analysis (MLSA). The characterization by MLSA was conducted using four housekeeping genes: $r p o B$ (RNA polymerase beta subunit); atpD (ATP synthase beta subunit); recA (recombinase A); and $\operatorname{trpB}$ (tryptophan synthetase subunit B). PCR amplifications were performed using primers previously described by Guo et al. (2008) (Table 1). The PCR mix $(25 \mu l)$ contained $1 \times$ Buffer, $3 \mathrm{mM}$ of $\mathrm{MgCl}_{2}, 200 \mu \mathrm{M}$ of dNTP, $10 \mathrm{pmol}$ of each primer, $10 \% \mathrm{v} / \mathrm{v}$ dimethylsulfoxide (DMSO), $1.25 \mathrm{U}$ of Taq DNA polymerase (recombinant) (Thermo Scientific), and $50 \mathrm{ng}$ of DNA template. The MLSA genes were amplified using thermal cycling conditions described by Guo et al. (2008) with some modification in annealing temperatures (Table 1). Amplified DNA fragments were separated on $1.5 \%$ agarose gels and visualized with ethidium bromide under UV light.

Amplicon purification, gene sequencing and sequence editing. Amplicons were purified and sequenced in both directions by the Macrogen Service (Geumcheon-gu, Seoul). Sequences were edited and assembled using Geneious Pro 4.8.5 software (Biomatters, Auckland, New Zealand) and deposited in the GenBank database. Sequences were compared with the GenBank nr database using the BLAST algorithm (Altschul et al. 1997).

Phylogenetic analyses. Phylogenetic analysis of $r p o B$ was conducted using sequences of an uninterrupted 306-bp internal fragment of a subset of 52 pathogenic Streptomyces isolates chosen as representative of different morphological and physiological characteristics present among the 70 strains and the following reference strains: S. stelliscabiei DSM41803; S. scabiei DSM41658; S. acidiscabies DSM41668; and S. turgidiscabies DSM41838. The sequences of an additional five reference Streptomyces strains (S. scabiei ATCC49173, S. acidiscabies ATCC49003, S. turgidiscabies ATCC700248, S. europaeiscabiei CFBP4497, and S. ipomoeae DSM40383) and S. flavidofuscus DSM43111, used as an outgroup, were obtained from public databases and were also included in the analysis. All sequences were aligned using ClustalW in MEGA 5.0 software (Tamura et al. 2011).

For MLSA, sequences of 28 pathogenic Streptomyces isolates from Uruguay with different characteristics were analyzed. The sequences of 11 pathogenic Streptomyces spp. deposited in GenBank were also included in the analysis: $S$. scabiei $87.22 ;$ S. acidiscabies 84-104; S. europaeiscabiei NRRL B-24443; S. luridiscabiei LMG 21390; S. niveiscabiei NRRL B-24457; S. puniciscabiei NRRL B-24456; S. caviscabies AS 4.1836; S. reticuliscabiei NRRL B-24446; S. stelliscabiei NRRL B-24447; S. turgidiscabies NRRL B- 24078; and S. ipomoeae NRRL B-12321 (causing scab in sweet potato). Sequences of Streptomyces flavidofuscus AS 4.1617 was included as an outgroup for the phylogenetic analysis. All sequences of each gene were concatenated and then aligned using ClustalW in MEGA 5.0 software (Tamura et al. 2011). Sequences were concatenated following the alphabetic order of the genes, ending in a large sequence of $2111 \mathrm{bp}(a t p D, \operatorname{rec} A, r p o B$, and $\operatorname{trp} B)$.

Phylogenetic trees for individual genes and the tree constructed from concatenated sequences alignment of four genes were inferred using the neighbor-joining (Saitou and Nei 1987), and maximumparsimony (Fitch 1972) methods. The distance (percent divergence) was calculated between all pairs of sequences based on the alignment. The neighbor-joining and maximum-parsimony methods were done using MEGA 5.0 (Tamura et al. 2011). The resultant neighbor-joining

Table 1. PCR primers and conditions used for Streptomyces isolated in Uruguay

\begin{tabular}{|c|c|c|c|c|}
\hline Gene/region & Primers & Nucleotide sequence $\left(5^{\prime}-3^{\prime}\right)$ & $\begin{array}{l}\text { Amplicon } \\
\text { size (bp) }\end{array}$ & $\begin{array}{c}\text { Annealing } \\
\text { temperature }\left({ }^{\circ} \mathrm{C}\right)\end{array}$ \\
\hline \multicolumn{5}{|l|}{ PAI markers genes } \\
\hline \multirow[t]{2}{*}{ necl } & $\mathrm{Nf}$ & ATGAGCGCGAACGGAAGCCCCGGA & 700 & 60 \\
\hline & $\mathrm{Nr}$ & GCAGGTCGTCACGAAGGATCG & & \\
\hline \multirow[t]{2}{*}{ txtA } & TxtA1 & CACGTACGCGCAGTTCAATG & 398 & 48 \\
\hline & TxtA2 & AGATGATGTAGGCGGGACTC & & \\
\hline \multirow[t]{2}{*}{$\operatorname{txt} A B$} & TxtAB1 & CCACCAGGACCTGCTCTTC & 385 & 48 \\
\hline & TxtAB2 & TCGAGTGGACCTCACAGATG & & \\
\hline \multirow[t]{2}{*}{ tomA } & Tom3 & GAGGCGTTGGTGGAGTTCTA & 392 & 55 \\
\hline & Tom4 & TTGGGGTTGTACTCCTCGTC & & \\
\hline \multicolumn{5}{|c|}{ Phylogenetic marker gene } \\
\hline \multirow[t]{2}{*}{ rрoв } & SRPOF1 & TCGACCACTTCGGCAACCGC & 352 & 56 \\
\hline & SRPOR1 & TCGATCGGGCACATGCGGCC & & \\
\hline \multicolumn{5}{|c|}{ 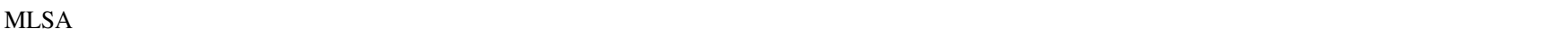 } \\
\hline \multirow{2}{*}{ atpD } & atpDPF & GTCGGCGACTTCACCAAGGGCAAGGTGTTCAACACC & 998 & 61 \\
\hline & atpDPR & GTGAACTGCTTGGCGACGTGGGTGTTCTGGGACAGGAA & & \\
\hline \multirow[t]{2}{*}{ recA } & recAPF & CCGCRCTCGCACAGATTGAACGSCAATTC & 913 & 65 \\
\hline & recAPR & GCSAGGTCGGGGTTGTCCTTSAGGAAGTTGCG & & \\
\hline \multirow[t]{2}{*}{ rров } & rpoBPF & GAGCGCATGACCACCCAGGACGTCGAGGC & 994 & 65 \\
\hline & rpoBPR & CCTCGTAGTTGTGACCCTCCCACGGCATGA & & \\
\hline \multirow[t]{2}{*}{$\operatorname{trp} B$} & $\operatorname{trpBPF}$ & GCGCGAGGACCTGAACCACACCGGCTCACACAAGATCAACA & 822 & 67 \\
\hline & $\operatorname{trpBPR}$ & TCGATGGCCGGGATGATGCCCTCGGTGCGCGACAGCAGGC & & \\
\hline \multicolumn{5}{|c|}{ 200 } \\
\hline BOX elements & BOXA1R & CTACGGCAAGGCGACGCTGACG & - & 50 \\
\hline \multirow[t]{2}{*}{ ERIC elements } & ERIC2 & AAGTAAGTGACTGGGGTGAGCG & - & 50 \\
\hline & ERIC1R & ATGTAAGCTCCTGGGGATTCAC & & \\
\hline
\end{tabular}


tree and topology were evaluated using 1000 bootstrap resamplings (Hillis and Bull 1993).

\section{Results}

CS pathogens were collected from 2010 through 2012 from fields located in the main potato-production regions in Uruguay. Tubers sampled in this survey exhibited diverse symptoms, ranging from mild, superficial, to deep-pitted lesions (Fig. 1). A total of 331 Streptomyces isolates were obtained from both necrotic tuber lesions and soils.

Pathogenicity. Only 70 Streptomyces spp. isolates of the 331 were determined to be pathogenic, including 45 isolates from necrotic lesions on potato tubers and 25 isolates from soil samples (Table 2). The 70 pathogenic isolates were designated based on a plant pathogenic phenotype on potato tuber slices and radish seedlings (Fig. 2). All pathogenic isolates were tested for presence of genes $t x t A, t x t B$, necl, and tomA, which are characteristic of the Streptomyces PAI (Table 2). The thaxtomin biosynthesis genes $t x t A$ and $t x t B$ were present in $77 \%$ of the pathogenic isolates. Among the isolates that were pathogenic, 50\% contain the four pathogenicity genes and $17 \%$ did not contain any genes for which they were tested.

Sequence scanning of virulent factors in draft genomes of ST1020 and ST1015. In order to confirm the PCR results and corroborate the absence of virulence factors among the $17 \%$ of isolates, we selected two representative strains, ST1020 and ST1015, and we conducted a whole-genome sequencing of these strains. Our objective was to obtain draft genomes with high coverage $(100 \times)$ that could be used for gene content analysis. Whole genome sequencing and assembly produced 1,569 contigs for strain ST1015 and 1,428 contigs for strain ST1020. The N50 of strain ST1015 and ST1020 were 14,127 bp and $17,382 \mathrm{bp}$, respectively. Resulting contigs were used as a nucleotide sequence database for BLAST searching. The sequences of the virulent factors were used as queries; there were no hits for any of the virulence factors among the draft genomes. The results confirmed the absence of known virulence factors in ST1020 and ST1015.

Morphological and physiological traits. A total of 331 isolates formed colonies phenotypically characteristic of Streptomyces spp. when grown on yeast malt extract (YME) media. Seventy pathogenic isolates and five reference strains were compared for colony and spore color en masse. Appearance and colony and spore color varied among isolates on YME media. Pathogenic isolates had colony colors ranging from cream to brown and produced spores ranging in color from white and light gray to dark gray. Based on spore and colony color, melanin production, and raffinose utilization, six different phenotypes were found: G/Be/M/R; G/Be/m/NT; G/Br/M/R; W/Be/ $\mathrm{M} / \mathrm{NT}$; W/Br/m/r; and W/Br/M/NT (Table 2). These morphological and physiological traits, though consistent with previous studies (Wanner 2006), did not provide sufficient information to distinguish Streptomyces isolates at the species level.

Genotyping using rep-PCR. BOX and ERIC-PCR techniques were employed to analyze the genetic variability among 70 isolates of Streptomyces spp. causing potato common scab in Uruguay and five reference strains. The duplicate trees of each isolate exhibited similar topologies on both rep-PCR techniques. A high genetic diversity among the isolates of pathogenic Streptomyces spp. can be seen in the combined dendogram (Fig. 3). This method allowed differentiation of the five reference strains used: $S$. acidiscabies; $S$. scabiei; $S$. turgidiscabies; S. europaeiscabiei; and S. stelliscabiei. The cluster analysis of banding patterns revealed that some isolates cluster in proximity to reference strains. Ten isolates were associated with the reference strain of $S$. acidiscabies. Fifteen isolates were associated with $S$. scabiei and four with S. turgidiscabies. The isolate ST1229 was clustered with the reference strain of $S$. europaeiscabiei and the isolate ST1218 with S. stelliscabiei. Finally, 39 isolates were not associated with any Streptomyces spp. for which they were tested.

Phylogenetic analysis of rpoB. The rpoB phylogenetic analysis revealed genetic variation among the 52 pathogenic Streptomyces isolates representing distinct morphological and physiological phenotypes and different genetic profiles determined by rep-PCR analysis. In the tree shown in Figure 4, Group I (10 isolates) clustered close to $S$. acidiscabies reference strains. The Group II (15 isolates) form a distinct cluster related to Group I. Group III (12 isolates) clustered with or in close proximity to $S$. scabiei and S. stelliscabiei. Group IV consisted of five isolates that are in the same cluster with S. europaeiscabiei and S. turgidiscabies. On the other hand, 10 isolates did not cluster closed to any of the reference Streptomyces strains used in this analysis.

Multi locus sequence analysis (MLSA). MLSA analysis based on the comparison of partial sequences of the four housekeeping genes was performed for 28 isolates of Streptomyces spp. representing the different groups formed in the phylogenetic analysis of $r p o B$ gene. The analysis allows differentiation of all Streptomyces pathogenic species. MLSA confirms the high genetic variability among the pathogenic Streptomyces spp. isolated in Uruguay. Overall, a good correlation was found with the previous groups identified by rpoB phylogenetic analysis, although a better level of discrimination between the different Streptomyces spp. was achieved by MLSA. The phylogenetic tree based on the concatenated sequences formed the same four congruent groups distinguished previously (Fig. 5). Group I (nine isolates) associated with the reference strain of $S$. acidiscabies supported with a bootstrap of 100. Group II (eight isolates) associated with the reference strain of $S$. niveiscabiei with a bootstrap of 79, making up a distinct cluster close to that of Group I represented by $S$. acidiscabies. Group III (five isolates) associated with the reference strain of S. scabiei with a bootstrap of 100. The isolate ST1229 from Group IV cluster with the reference strain of S. europaeiscabiei with a bootstrap of 99 . Five of the 28 isolates did not cluster with any of the Streptomyces reference strain. In the present study, an isolate was assigned to a particular species if it was strongly associated in the same cluster to the corresponding reference strain, sharing high sequence identity $(>99 \%)$ along the concatenated partial sequences of $a t p D, \operatorname{rec} A, r p o B$, and $\operatorname{trp} B$ genes (see Table 2).

\section{Discussion}

This study constitutes the first extensive characterization of CSinciting Streptomyces spp. isolated from infected tubers and soils in Uruguay. The unusually significant economic losses due to the spread of CS in Uruguay in autumn 2010 prompted an urgent need to fully understand the CS pathogen complex in as much detail as

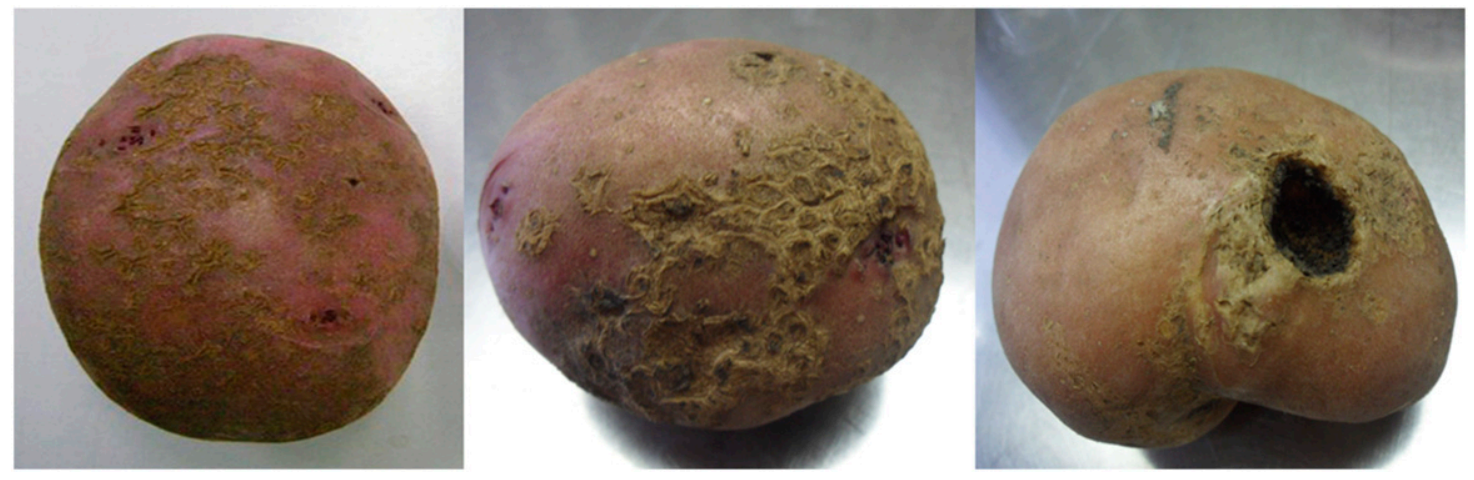

Fig. 1. CS symptom classification on potato tubers used in this study: left, superficial lesions; middle, raised lesions; and right, pitted lesions. 
possible (Lapaz et al. 2012). Streptomyces spp. causing CS on potato in Uruguay were comprised of a range of different species, distinguished by diverse morphological and physiological properties as well as by rep-PCR, $r p o B$ sequence analysis, and multi locus sequences analysis. Seventy pathogenic Streptomyces spp. were characterized in the present study: 10 could be assigned to $S$. acidiscabies (Group I); 12 to S. scabiei (Group III); 1 isolate as S. europaeiscabiei (Group IV); and 15 isolates clustered in proximity to $S$. neiveiscabie (Group II) (Table 2). Thirty-two of the 70 isolates analyzed could not be assigned to any of the five principal CS species investigated here. These isolates may be related to other pathogens of described species within the genus Streptomyces and were not evaluated further in this survey.

A high genetic diversity among the pathogenic Streptomyces spp. isolated in Uruguay can be seen in the combined dendrogram of (Fig. $3)$. Phylogenetic analysis based on $r p o B$ sequences was reported as a powerful tool for phylogenetic analysis and species differentiation within the genera Streptomyces and Kitasatospora (Kim et al. 2004). However, our results revealed that $r p o B$ phylogeny is not reliable, indicating that $r p o B$ alone is not enough for Streptomyces spp. identification. The phylogenetic tree obtained by $r р о B$ sequence comparison showed low bootstrap support and did not infer the correct evolutionary relationships among Streptomyces spp. For example, it has been reported that $S$. europaescabiei is closely related to S. scabiei (Bouchek-Mechiche et al. 2000); however, in Figure 4, $S$. europaescabiei is close to $S$. turgidiscabies but distant from
S. scabiei. In addition, S. scabiei and S. stelliscabiei were in the same cluster in the $r p o B$ sequence analysis, suggesting that the $r p o B$ fragment used in this study was not generally suitable for distinguishing all Streptomyces spp. causing CS. Phylogenetic relationships of the tree, constructed from the concatenated sequence alignment of four housekeeping genes (2111 bp) (Fig. 5), largely agreed with those inferred from analysis of $r p o B$ gene sequences (Fig. 4), but bootstrap support for these groupings was significantly higher. In addition, MLSA analysis allowed us to differentiate $S$. scabiei and S. stelliscabiei species and to identify isolates such as $S$. scabiei, which were previously identified as $S$. scabiei/S. stelliscabiei by phylogenetic analysis of $r p o B$. These isolates had morphological and physiological characteristics similar to type strains of $S$. scabiei and S. stelliscabiei. They produced gray spores, melanin on tyrosine agar medium, and utilized raffinose as a carbon source (Table 2). Streptomyces scabiei is worldwide in its distribution and is dominant in the United States (Dees and Wanner 2012).

The identity of isolates previously clustered with $S$. acidiscabies by rep-PCR were confirmed through partial sequencing of $r p o B$ gene and MLSA. These isolates had morphological and physiological characteristics similar to those of $S$. acidiscabies type strain DSM41668. They produced white spores, did not produce melanin on tyrosine agar, and did not utilize raffinose as a carbon source. Streptomyces acidiscabies was first isolated from low pH soils in the United States (Lambert and Loria 1989a) and was later found

Table 2. Phenotypic and genetic characterization of Streptomyces spp. isolates predicted to cause CS on potato in Uruguay and reference strains

\begin{tabular}{|c|c|c|c|c|c|c|c|c|c|c|c|c|c|}
\hline \multirow{3}{*}{$\begin{array}{l}\text { Isolate/type } \\
\text { strain }\end{array}$} & \multirow[b]{3}{*}{ Genera/species ${ }^{\text {a }}$} & \multirow{2}{*}{\multicolumn{2}{|c|}{ Origin }} & \multicolumn{2}{|c|}{ Sample } & \multicolumn{4}{|c|}{ Morphological and physiological traits } & \multirow{2}{*}{\multicolumn{3}{|c|}{ PAI marker genes ${ }^{\mathbf{e}}$}} & \multirow[b]{3}{*}{ Analysis ${ }^{f}$} \\
\hline & & & & \multirow{2}{*}{$\begin{array}{c}\text { Source of } \\
\text { isolates }\end{array}$} & \multirow[b]{2}{*}{ Symptom } & \multirow{2}{*}{$\begin{array}{l}\text { Spore } \\
\text { colorb }^{b}\end{array}$} & \multirow{2}{*}{$\begin{array}{c}\text { Colony } \\
\text { color }^{b}\end{array}$} & \multirow{2}{*}{$\underset{\text { production }^{c}}{\text { Melanin }}$} & \multirow{2}{*}{$\begin{array}{c}\text { Raffinose } \\
\text { utilization }^{d}\end{array}$} & & & & \\
\hline & & Year & Location & & & & & & & txtAB & nec1 & $\operatorname{tom} A$ & \\
\hline ST103 & Sac & 2010 & San José & Tubers & Pitted & $\mathrm{W}$ & $\mathrm{Br}$ & $\mathrm{m}$ & $\mathrm{r}$ & + & + & + & rep/rpoB/MLSA \\
\hline ST104 & Sac & 2010 & San José & Tubers & Pitted & $\mathrm{W}$ & $\mathrm{Br}$ & $\mathrm{m}$ & $\mathrm{r}$ & + & + & + & rep/rpoB \\
\hline ST105 & $\mathrm{Sac}$ & 2010 & San José & Tubers & Pitted & $\mathrm{W}$ & $\mathrm{Br}$ & $\mathrm{m}$ & $\mathrm{r}$ & + & + & + & rep/rpoB/MLSA \\
\hline ST106 & $\mathrm{Sac}$ & 2010 & San José & Tubers & Pitted & $\mathrm{W}$ & $\mathrm{Br}$ & $\mathrm{m}$ & $\mathrm{r}$ & + & + & + & rep/rpoB/MLSA \\
\hline ST107 & Ssp & 2010 & San José & Tubers & Pitted & W & $\mathrm{Br}$ & $\mathrm{m}$ & $\mathrm{r}$ & - & + & - & rep/rpoB/MLSA \\
\hline ST108 & Ssp & 2010 & San José & Tubers & Pitted & W & $\mathrm{Br}$ & $\mathrm{m}$ & $\mathrm{r}$ & - & - & - & rep/rpoB/MLSA \\
\hline ST109 & Ssp & 2010 & San José & Tubers & Pitted & $\mathrm{W}$ & $\mathrm{Br}$ & $\mathrm{m}$ & $\mathrm{r}$ & - & - & - & rep/rpoB/MLSA \\
\hline ST1010 & Ssp & 2010 & San José & Tubers & Pitted & W & $\mathrm{Br}$ & $\mathrm{m}$ & $\mathrm{r}$ & + & + & - & $\mathrm{rep} / r p o B$ \\
\hline ST1011 & Ssp & 2010 & San José & Tubers & Pitted & W & $\mathrm{Br}$ & $\mathrm{m}$ & $\mathrm{r}$ & + & - & - & rep/rpoB/MLSA \\
\hline ST1012 & Ssp & 2010 & San José & Tubers & Pitted & $\mathrm{W}$ & $\mathrm{Br}$ & $\mathrm{m}$ & $\mathrm{r}$ & - & - & - & rep/rpoB \\
\hline ST1013 & Ssp & 2010 & San José & Tubers & Pitted & $\mathrm{W}$ & $\mathrm{Br}$ & $\mathrm{m}$ & $\mathrm{r}$ & - & - & - & rep/rpoB/MLSA \\
\hline ST1014 & Ssp & 2010 & San José & Tubers & Pitted & $\mathrm{W}$ & $\mathrm{Br}$ & $\mathrm{m}$ & $\mathrm{r}$ & - & - & - & rep/rpoB \\
\hline ST1015 & Ssp & 2010 & Canelones & Tubers & Pitted & $\mathrm{W}$ & $\mathrm{Br}$ & $\mathrm{m}$ & $\mathrm{r}$ & - & - & - & rep/rpoB/MLSA \\
\hline ST1016 & Ssp & 2010 & Canelones & Tubers & Pitted & $\mathrm{W}$ & $\mathrm{Br}$ & $\mathrm{m}$ & $\mathrm{r}$ & - & + & - & rep/rpoB \\
\hline ST1017 & Ssp & 2010 & Canelones & Tubers & Pitted & $\mathrm{W}$ & $\mathrm{Br}$ & $\mathrm{m}$ & $\mathrm{r}$ & - & - & - & rep/rpoB \\
\hline ST1018 & Ssp & 2010 & Canelones & Tubers & Pitted & W & $\mathrm{Br}$ & $\mathrm{m}$ & $\mathrm{r}$ & + & + & - & rep/rpoB/MLSA \\
\hline ST1019 & Ssp & 2010 & Canelones & Tubers & Pitted & W & $\mathrm{Br}$ & $\mathrm{m}$ & $\mathrm{r}$ & - & - & - & $\mathrm{rep} /$ rpoB \\
\hline ST1020 & Ssp & 2010 & Canelones & Tubers & Pitted & W & $\mathrm{Br}$ & $\mathrm{m}$ & $\mathrm{r}$ & - & - & - & rep/rpoB/MLSA \\
\hline ST1021 & Ssp & 2010 & Canelones & Tubers & Pitted & $\mathrm{W}$ & $\mathrm{Br}$ & $\mathrm{m}$ & $\mathrm{r}$ & - & - & - & rep/rpoB \\
\hline ST111 & Sac & 2011 & San José & Tubers & Superficial & $\mathrm{W}$ & $\mathrm{Br}$ & $\mathrm{m}$ & $\mathrm{r}$ & + & + & + & rep/rpoB/MLSA \\
\hline ST112 & $\mathrm{Sac}$ & 2011 & San José & Tubers & Superficial & $\mathrm{W}$ & $\mathrm{Br}$ & $\mathrm{m}$ & $\mathrm{r}$ & + & + & + & rep/rpoB/MLSA \\
\hline ST113 & $\mathrm{Sac}$ & 2011 & Rocha & Tubers & Raised & $\mathrm{W}$ & $\mathrm{Br}$ & $\mathrm{m}$ & $\mathrm{r}$ & + & + & + & rep/rpoB/MLSA \\
\hline ST114 & $\mathrm{Sac}$ & 2011 & Rocha & Tubers & Superficial & $\mathrm{W}$ & $\mathrm{Br}$ & $\mathrm{m}$ & $\mathrm{r}$ & + & + & + & rep/rpoB/MLSA \\
\hline ST115 & Sac & 2011 & Rocha & Tubers & Raised & $\mathrm{W}$ & $\mathrm{Br}$ & $\mathrm{m}$ & $\mathrm{r}$ & + & + & + & rep/rpoB/MLSA \\
\hline ST116 & $\mathrm{Sac}$ & 2011 & San José & Tubers & Pitted & W & $\mathrm{Br}$ & $\mathrm{m}$ & $\mathrm{r}$ & + & + & + & rep/rpoB/MLSA \\
\hline ST119 & Ssp & 2011 & San José & Soil & & $\mathrm{W}$ & $\mathrm{Be}$ & M & NT & + & + & + & rep/rpoB/MLSA \\
\hline ST1113 & Ssc & 2011 & San José & Tubers & Raised & G & $\mathrm{Br}$ & M & $\mathrm{R}$ & + & + & + & rep/rpoB/MLSA \\
\hline ST1114 & Ssc & 2011 & San José & Tubers & Pitted & G & $\mathrm{Br}$ & M & $\mathrm{R}$ & + & + & + & rep/rpoB \\
\hline ST1116 & Ssp & 2011 & Seed & Tubers & & $\mathrm{W}$ & $\mathrm{Be}$ & M & NT & + & - & + & rep \\
\hline ST1118 & Ssp & 2011 & San José & Soil & & $\mathrm{W}$ & $\mathrm{Be}$ & NT & NT & + & + & - & $\mathrm{rep} /$ rpoB \\
\hline ST1119 & Ssp & 2011 & San José & Soil & & W & $\mathrm{Be}$ & $\mathrm{m}$ & NT & - & - & - & $\mathrm{rep} / \mathrm{rpoB}$ \\
\hline ST1121 & Ssp & 2011 & San José & Soil & & G & $\mathrm{Br}$ & M & NT & + & + & $\begin{array}{l}- \\
\text { (con }\end{array}$ & $\begin{array}{l}\text { rep } \\
\text { zued on next page) }\end{array}$ \\
\hline
\end{tabular}

${ }^{a}$ Ssp. $=$ Streptomyces $\mathrm{spp} ., \mathrm{Ssc}=$ S. scabiei, Stu $=$ S. turgidiscabies, $\mathrm{Sac}=$ S. acidiscabies, $\mathrm{Seu}=$ S. europaeiscabiei, and Sst $=$ S. stelliscabiei.

${ }^{\mathrm{b}} \mathrm{G}=$ gray, $\mathrm{W}=$ white, $\mathrm{Br}=$ brown, and $\mathrm{Be}=$ beige.

${ }^{\mathrm{c}} \mathrm{M}=$ production of melanin, $\mathrm{m}=$ No production of melanin, and $\mathrm{NT}=$ not tested.

${ }^{\mathrm{d}} \mathrm{R}=$ Utilization of raffinose, and $\mathrm{r}=$ no utilization of raffinose.

e Presence (+) or absence (-) of genes associated with the Streptomyces PAI.

${ }^{\mathrm{f}} \mathrm{rep}=\mathrm{BOX}$ and ERIC-PCR, $r p o B=$ Phylogenetic analysis of $r p o B$, and MLSA = multi locus sequence analysis. Words in bold type indicate the method/s used for species assignation for each Streptomyces isolate. In this study, an isolate was assigned to a particular species if it was strongly associated in the same cluster to the corresponding reference strain, sharing high sequence identity (>99\%) along the concatenated partial sequences of $\operatorname{atpD}$, $\operatorname{rec} A$, $r p o B$, and $\operatorname{trpB}$ genes. Some strains not analyzed by MLSA were identified based on rep-PCR or rpoB phylogeny, only if they were strongly associated with a reference strain or with an isolate assigned previously by MLSA. 
in Canada, China, Japan, Korea, the UK, and Uruguay (Dees and Wanner 2012; Lapaz et al. 2012).

Group II is associated with the reference strain of S. niveiscabiei in MLSA, reported in Korea (Park et al. 2003). This group is near Group I in both phylogenetic analyses. The isolate ST1229 was identified as S. europaeiscabiei using the MLSA approach and presented similar phenotypical characteristics to said species. This constituted the first report of this pathogenic species in Uruguay. Streptomyces europaeiscabiei is dominant in Europe (Bouchek-Mechiche et al. 2000; Dees et al. 2013; Flores-Gonzalez et al. 2008; Leiminger et al. 2013), but has also been reported in Canada, Korea, and the United States (Song et al. 2004; Wanner 2006). Phylogenetic analyses and rep-PCR showed a vast diversity of pathogenic isolates that have not been identified yet. This would suggest that there may be emerging pathogens that cause common scab, possibly due to the horizontal transference of PAIs from pathogenic to saprophytic Streptomyces spp. (Bukhalid et al. 2002; Healy et al. 1999; Kers et al. 2005). Based on the results obtained from this work, the best method would be MLSA (Labeda 2011), as it allows the distinction of each Streptomyces spp. causing common scab.

The isolates investigated in this study were obtained from lesions with varied symptoms, ranging from superficial to raised or pitted lesions (Fig. 1). There was no correlation, however, between a particular assigned species and a given type of symptom. Both $S$. acidiscabies and S. scabiei were identified in samples of tissue with, e.g., superficial, raised, or pitted scab symptoms; these results are in accordance with previous studies indicating that symptoms were not species-specific (Dees et al. 2013; Loria et al. 1997). Rather, severity of symptoms seems to be influenced by inoculum level in the soil, susceptibility of the potato cultivar, as well as virulence of the pathogen strain (Loria et al. 1997).

The presence of PAI marker genes in Uruguayan Streptomyces isolates was found to be highly variable. Six of eight possible combinations of the four PAI markers were found among the 70 pathogenic isolates. Among the isolates that were pathogenic, $50 \%$ have

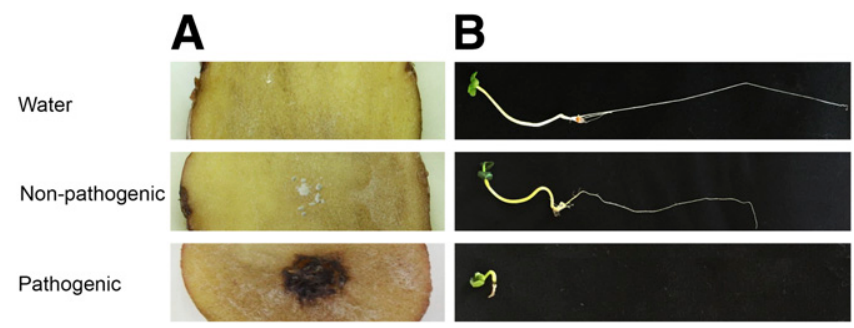

Fig. 2. Pathogenicity assays on different plant hosts. A, a potato tuber slices bioassay; and $\mathbf{B}$, a radish seedling bioassay. Negative control (on the top), nonpathogenic phenotype (middle), and plant-pathogenic phenotype (on the bottom).

Table 2. (continued from preceding page)

\begin{tabular}{|c|c|c|c|c|c|c|c|c|c|c|c|c|c|}
\hline \multirow{3}{*}{$\begin{array}{l}\text { Isolate/type } \\
\text { strain }\end{array}$} & \multirow[b]{3}{*}{ Genera/species ${ }^{\mathbf{a}}$} & \multirow{2}{*}{\multicolumn{2}{|c|}{ Origin }} & \multirow{3}{*}{\multicolumn{2}{|c|}{ 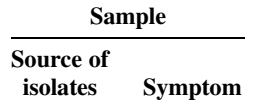 }} & \multicolumn{4}{|c|}{ Morphological and physiological traits } & \multirow{2}{*}{\multicolumn{3}{|c|}{ PAI marker genes ${ }^{\mathbf{e}}$}} & \multirow[b]{3}{*}{ Analysis ${ }^{\mathbf{f}}$} \\
\hline & & & & & & \multirow{2}{*}{$\begin{array}{l}\text { Spore } \\
\text { colorb }^{b}\end{array}$} & \multirow{2}{*}{$\begin{array}{l}\text { Colony } \\
\text { color }^{\mathrm{b}}\end{array}$} & \multirow{2}{*}{$\underset{\text { production }^{\mathrm{c}}}{\text { Melanin }}$} & \multirow{2}{*}{$\begin{array}{c}\text { Raffinose } \\
\text { utilization }^{d}\end{array}$} & & & & \\
\hline & & Year & Location & & & & & & & $t x t A B$ & necl & $\operatorname{tom} A$ & \\
\hline ST1123 & Ssp & 2011 & San José & Soil & & G & $\mathrm{Br}$ & $\mathrm{m}$ & NT & + & - & - & rep \\
\hline ST1124 & Ssp & 2011 & San José & Soil & & G & $\mathrm{Br}$ & $\mathrm{m}$ & NT & + & + & + & $\mathrm{rep} /$ rpoB \\
\hline ST1125 & Ssp & 2011 & San José & Soil & & G & $\mathrm{Br}$ & M & NT & + & + & + & $\mathrm{rep} / r p o B$ \\
\hline ST1127 & Ssp & 2011 & San José & Soil & & G & $\mathrm{Br}$ & $\mathrm{m}$ & NT & + & + & - & rep \\
\hline ST1128 & Ssp & 2011 & San José & Soil & & W & $\mathrm{Br}$ & $\mathrm{m}$ & NT & + & + & + & rep \\
\hline ST1131 & Ssp & 2011 & San José & Soil & & G & $\mathrm{Br}$ & M & NT & + & - & + & $\mathrm{rep} /$ rpoB \\
\hline ST1133 & Ssp & 2011 & San José & Soil & & W & $\mathrm{Br}$ & $\mathrm{m}$ & NT & - & - & - & $\mathrm{rep} / r p o B$ \\
\hline ST1134 & Ssp & 2011 & San José & Soil & & G & $\mathrm{Br}$ & NT & NT & + & + & + & $\mathrm{rep} / r p o B / \mathrm{MLSA}$ \\
\hline ST1135 & Ssp & 2011 & San José & Soil & & W & $\mathrm{Be}$ & $\mathrm{M}$ & NT & + & - & - & rep \\
\hline ST1136 & Ssp & 2011 & San José & Soil & & $\mathrm{W}$ & $\mathrm{Br}$ & $\mathrm{M}$ & NT & + & - & + & rep \\
\hline ST1137 & Ssp & 2011 & San José & Soil & & G & $\mathrm{Br}$ & NT & NT & - & - & + & rep \\
\hline ST1140 & Ssp & 2011 & Seed & Tubers & Raised & G & $\mathrm{Br}$ & $\mathrm{M}$ & $\mathrm{R}$ & + & + & + & $\mathrm{rep} / r p o B / \mathrm{MLSA}$ \\
\hline ST1142 & Ssp & 2011 & San José & Soil & & G & $\mathrm{Br}$ & M & NT & + & + & - & rep \\
\hline ST121 & Ssp & 2012 & San José & Tubers & Pitted & W & $\mathrm{Br}$ & $\mathrm{m}$ & $\mathrm{r}$ & + & - & + & $\mathrm{rep} / r p o B / \mathrm{MLSA}$ \\
\hline ST123 & Ssp & 2012 & San José & Tubers & Pitted & G & $\mathrm{Be}$ & M & $\mathrm{R}$ & + & - & + & $\mathrm{rep} / r p o B$ \\
\hline ST124 & Ssc & 2012 & San José & Tubers & Superficial & G & $\mathrm{Br}$ & M & $\mathrm{R}$ & + & + & + & rep/rpoB/MLSA \\
\hline ST125 & Ssc & 2012 & San José & Tubers & Pitted & G & $\mathrm{Br}$ & M & $\mathrm{R}$ & + & + & + & rep/rpoB \\
\hline ST126 & Ssc & 2012 & San José & Tubers & Superficial & G & $\mathrm{Br}$ & M & $\mathrm{R}$ & + & + & + & rep/rpoB \\
\hline ST127 & Ssc & 2012 & San José & Tubers & Pitted & G & $\mathrm{Br}$ & M & NT & + & + & + & rep/rpoB/MLSA \\
\hline ST128 & Ssc & 2012 & San José & Tubers & Pitted & G & $\mathrm{Br}$ & M & $\mathrm{R}$ & + & + & + & rep/rpoB \\
\hline ST129 & Ssc & 2012 & San José & Tubers & Pitted & G & $\mathrm{Br}$ & M & $\mathrm{R}$ & + & + & + & rep/rpoB/MLSA \\
\hline ST1210 & Ssc & 2012 & San José & Tubers & Pitted & G & $\mathrm{Br}$ & M & $\mathrm{R}$ & + & + & + & rep/rpoB \\
\hline ST1211 & Ssp & 2012 & San José & Soil & & G & $\mathrm{Br}$ & M & NT & + & - & + & rep \\
\hline ST1212 & Ssp & 2012 & San José & Soil & & W & $\mathrm{Be}$ & M & NT & + & + & + & rep \\
\hline ST1213 & Ssp & 2012 & San José & Soil & & G & $\mathrm{Br}$ & $\mathrm{m}$ & NT & + & + & + & rep \\
\hline ST1214 & Ssp & 2012 & San José & Soil & & G & $\mathrm{Br}$ & $\mathrm{m}$ & NT & + & + & + & rep \\
\hline ST1218 & Ssp & 2012 & San José & Soil & & W & $\mathrm{Br}$ & $\mathrm{m}$ & NT & + & + & + & $\mathrm{rep} / r p o B / \mathrm{MLSA}$ \\
\hline ST1221 & Ssp & 2012 & San José & Soil & & $\mathrm{G}$ & $\mathrm{Br}$ & $\mathrm{m}$ & NT & + & - & - & rep \\
\hline ST1222 & Ssp & 2012 & San José & Soil & & W & $\mathrm{Be}$ & $\mathrm{m}$ & NT & - & + & - & rep \\
\hline ST1224 & Ssp & 2012 & San José & Soil & & G & $\mathrm{Br}$ & $\mathrm{m}$ & NT & + & + & - & rep \\
\hline ST1225 & Ssp & 2012 & San José & Soil & & G & $\mathrm{Br}$ & $\mathrm{m}$ & NT & + & - & - & rep \\
\hline ST1227 & Ssp & 2012 & San José & Tubers & Superficial & G & $\mathrm{Be}$ & M & NT & + & + & + & $\mathrm{rep} / r p o B$ \\
\hline ST1228 & Ssp & 2012 & San José & Tubers & Superficial & G & $\mathrm{Be}$ & $\mathrm{m}$ & NT & + & - & - & rep \\
\hline ST1229 & Seu & 2012 & San José & Tubers & Pitted & G & $\mathrm{Br}$ & M & $\mathrm{R}$ & + & + & + & rep/rpoB/MLSA \\
\hline ST1230 & Ssc & 2012 & San José & Tubers & Superficial & G & $\mathrm{Br}$ & M & $\mathrm{R}$ & + & + & + & rep/rpoB \\
\hline ST1232 & Ssc & 2012 & San José & Tubers & Superficial & G & $\mathrm{Br}$ & M & $\mathrm{R}$ & + & + & + & rep/rpoB/MLSA \\
\hline ST1234 & Ssp & 2012 & San José & Tubers & Superficial & G & $\mathrm{Br}$ & M & $\mathrm{R}$ & + & + & + & rep \\
\hline ST1236 & Ssc & 2012 & San José & Tubers & Superficial & G & $\mathrm{Br}$ & M & $\mathrm{R}$ & + & + & + & $\mathrm{rep} / r p o B$ \\
\hline DSM41658 & Ssc & & & & & G & $\mathrm{Br}$ & M & $\mathrm{R}$ & + & + & + & rep/rpoB \\
\hline DSM41803 & Sst & & & & & G & $\mathrm{Br}$ & M & $\mathrm{R}$ & + & + & + & $\mathrm{rep} / r p o B$ \\
\hline DSM41802 & Seu & & & & & G & $\mathrm{Br}$ & M & $\mathrm{R}$ & + & + & + & rep \\
\hline DSM41668 & $\mathrm{Sac}$ & & & & & W & $\mathrm{Br}$ & $\mathrm{m}$ & $\mathrm{r}$ & + & + & + & $\mathrm{rep} / r p o B$ \\
\hline DSM41838 & Stu & & & & & G & $\mathrm{Be}$ & $\mathrm{m}$ & $\mathrm{R}$ & + & + & + & $\mathrm{rep} / r p o B$ \\
\hline
\end{tabular}


BOX

ERIC
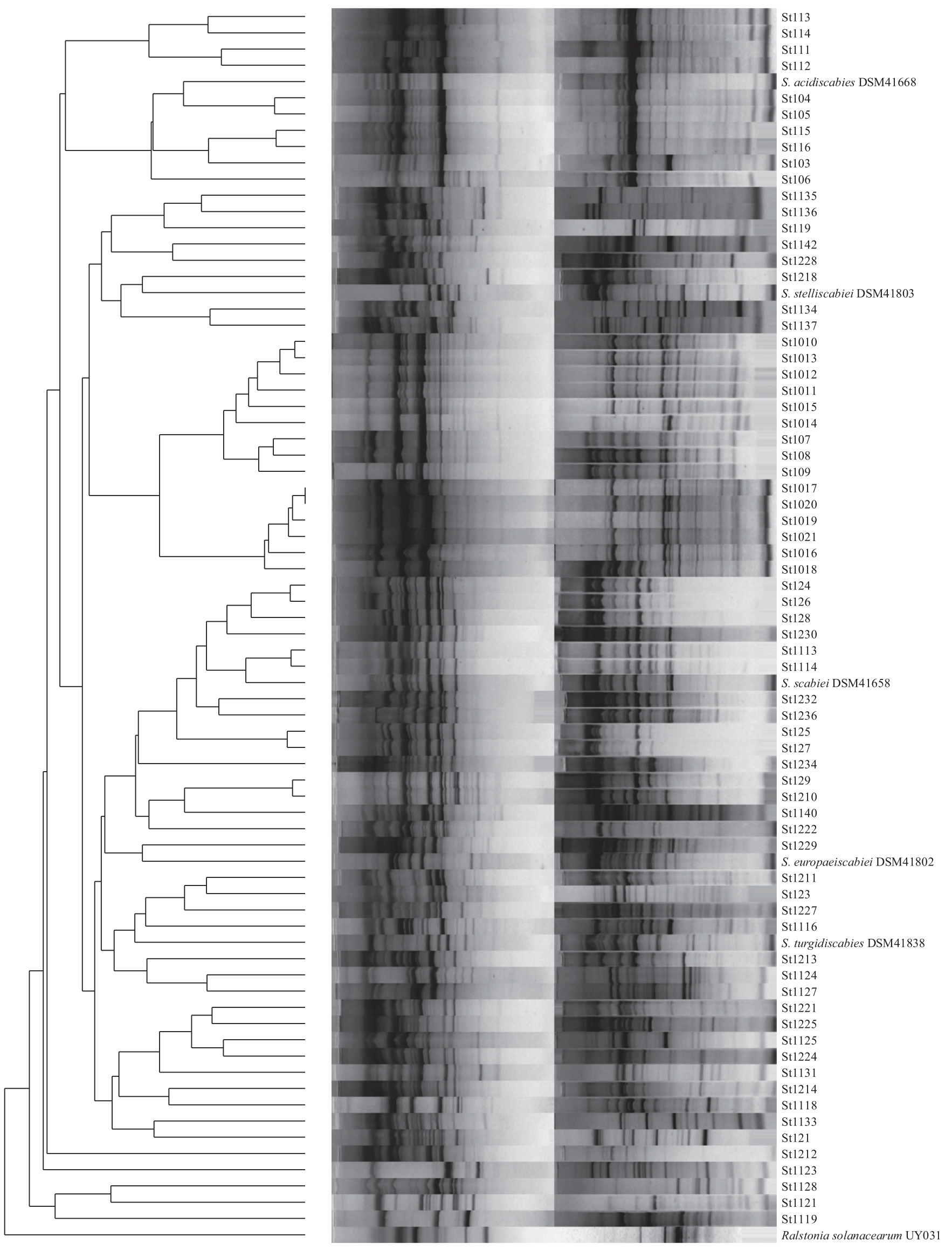

Fig. 3. Combined dendrogram based on repetitive sequence polymerase chain reaction (BOX/ERIC-PCR) fingerprints of 70 Streptomyces spp. isolates from Uruguay created using unweighted pair-group method using arithmetic averages (UPGMA) clustering of Dice coefficient values. Reference strains included in the dendrogram are DSM41658, DSM41803, DSM41802, DSM41668, DSM41838, and Ralstonia solanacearum strain UY031 as an outgroup (see Table 2 for details of the isolates). 


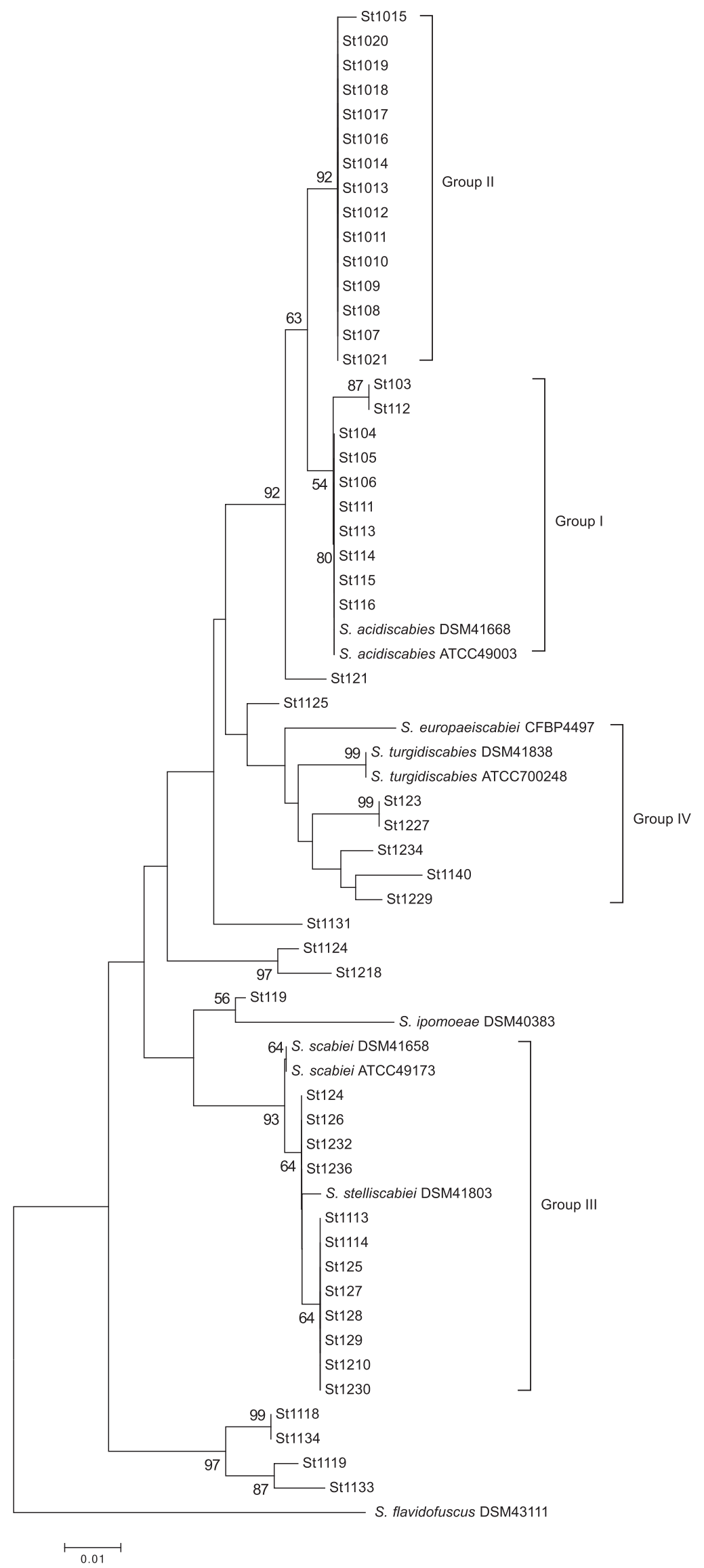

Fig. 4. Phylogenetic relationships between 52 Streptomyces spp. Uruguayan isolates and reference strains (see Table 2 for details on isolates and strains) based on partial nucleotide sequences (306 bp) of the gene rpoB. The tree was constructed using the neighbor-joining method. Percentages at nodes represent levels of bootstrap support from 1000 resampled datasets. Bootstrap values less than $50 \%$ are not shown. Streptomyces flavidofuscus DSM 43111 was used as outgroup. The bar represents a phylogenetic distance of 0.01 . 


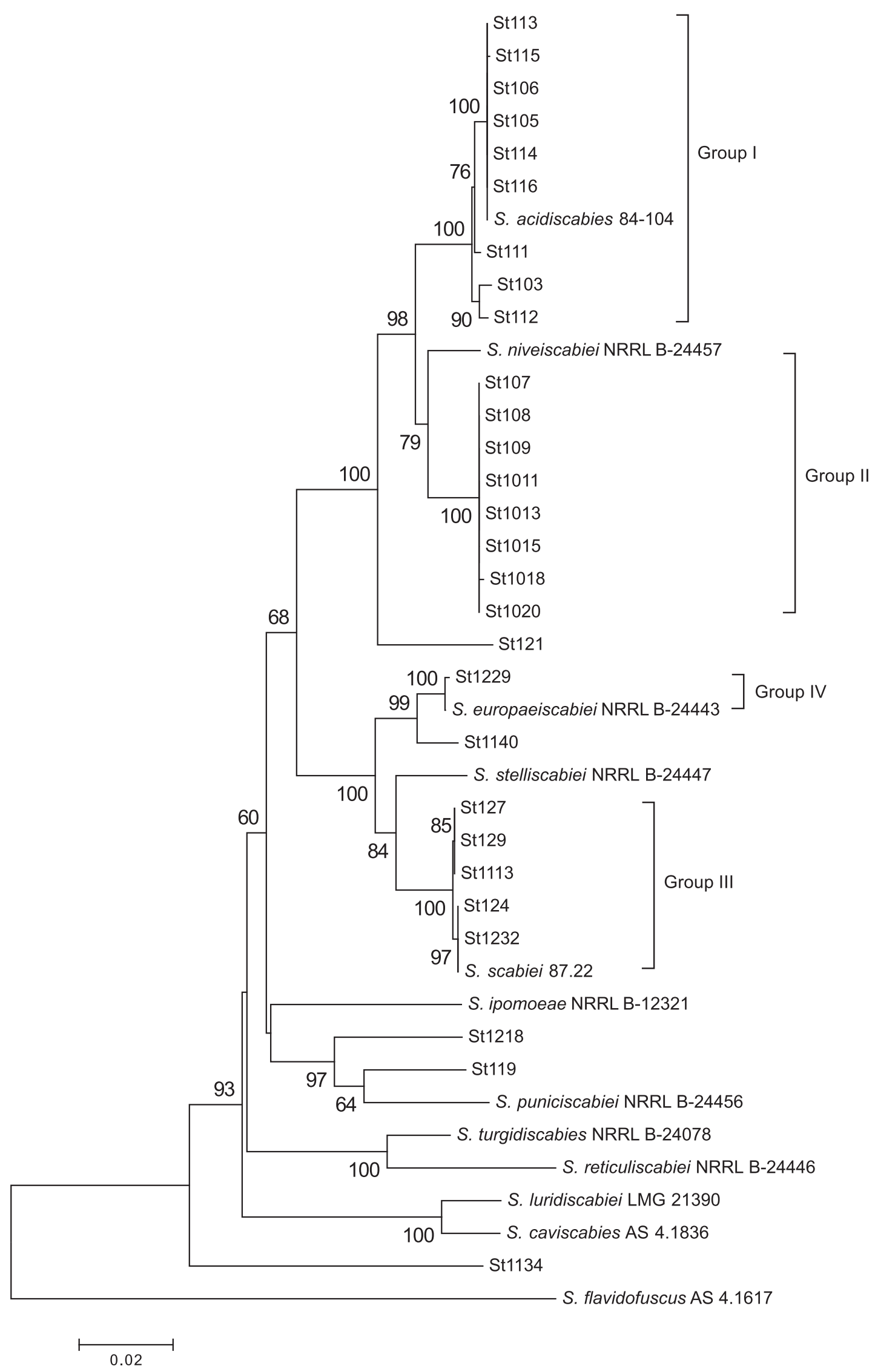

Fig. 5. Neighbor-joining tree based on concatenation of partial sequences of atpD, recA, rpoB, and trpB genes $(2111 \mathrm{pb})$ for 28 Streptomyces spp. isolates from Uruguay, 10 pathogenic reference strains, and S. flavidofuscus AS 4.1617 as an outgroup. Only bootstrap values higher than $50 \%$ are displayed at each node. The bar represents a phylogenetic distance of 0.02 .

1370 Plant Disease /Vol. 101 No. 8 
an atypical composition of PAI marker genes. We found that necl was missing from more than one of the pathogenic isolates tested. The tomatinase homolog-encoding gene tomA was absent in some pathogenic isolates, which was also consistent with previous studies showing that not all CS-inducing Streptomyces spp. are tomA+ (Wanner 2006). Both virulence-related genes, necl and tomA, have been reported to be present in many CS-inducing Streptomyces strains, but not in all, and they are not required for pathogenicity (Seipke and Loria 2008; Wanner 2009). Streptomyces lacking $t x t A B$ genes in 16 isolates were still able to cause pathogenicity. There have been only a few reports of pathogenic isolates that do not produce thaxtomins (Cao et al. 2012; Fyans et al. 2016; Pánková et al. 2012; Wanner 2004) and isolates seem to be geographically restricted. Unknown pathogenicity factors in addition to thaxtomins were recently suggested by comparative genomic analyses of $S$. scabiei 87-22 genome sequence (GenBank Accession No. NC_013929) (Bignell et al. 2010).

Twelve isolates that lacked all four pathogenicity marker genes were able to induce necrosis on potato slices and stunting of radish seedling (Table 2). The absence of pathogenicity genes was determined by PCR and confirmed by genomes sequencing analysis of two representative strains of this group. Jordaan and van der Waals (2016) reported pathogenic isolates with these characteristics. It is possible that these isolates have novel pathogenicity factors. Genetic variation regarding the presence or absence of genes associated with the Streptomyces PAI element can be expected in that it is known to be horizontally transferred as a unit or in modules by site-specific recombination (Huguet-Tapia et al. 2014; Zhang et al. 2016). It is also known that pathogenicity and virulence-related gene clusters in $S$. turgidiscabies have multiple origins, and that a given PAI consists of a mosaic of regions that may undergo independent evolution (Aittamaa et al. 2010). The heterogeneous composition of PAI, and the fact that species are constantly evolving, may contribute to the emergence of new pathogenic species.

This study shows that diversity of CS-inciting species in Uruguay is greater than previously thought and may include new, not previously reported Streptomyces spp. that are associated with CS. Genome sequencing studies for more CS strains isolated in Uruguay are ongoing. It is expected that their genomic analysis could contribute to clarification of the interesting results about the pathogenic behavior of these strains.

\section{Acknowledgments}

This work was supported by grant CSIC Productivo-Universidad de la República, Uruguay, Initiation, Master and Doctoral scholarships provided to M. I. Lapaz by the National Agency for Innovation and Research in Uruguay (ANII) and Comisión Académica de Posgrado (CAP), Universidad de la República. We thank P. Gill for critical review of the manuscript; Departamento de Protección Vegetal (Fitopatología), Facultad de Agronomía, Montevideo, Uruguay for providing Streptomyces spp. strains isolates from potato tubers; S. Menoni and N. Feller for help with figures; E. Condon and A. Rigos for linguistic revision.

\section{Literature Cited}

Aittamaa, M., Somervuo, P., Laakso, I., Auvinen, P., and Valkonen, J. 2010. Microarray-based comparison of genetic differences between strains of Streptomyces turgidiscabies with focus on the pathogenicity island. Mol. Plant Pathol. 11:733-746

Altschul, S. F., Madden, T. L., Schaffer, A. A., Zhang, J., Zhang, Z., Miller, W., and Lipman, D. J. 1997. Gapped BLAST and PSI-BLAST: a new generation of protein database search programs. Nucleic Acids Res. 25:3389-3402.

Bankevich, A., Nurk, S., Antipov, D., et al. 2012. SPAdes: a new genome assembly algorithm and its applications to single-cell sequencing. J. Comput. Biol. 19:455-477.

Bignell, D. R., Fyans, J. K., and Cheng, Z. 2014. Phytotoxins produced by plant pathogenic Streptomyces species. J. Appl. Microbiol. 116:223-235.

Bignell, D. R., Huguet-Tapia, J. C., Joshi, M. V., Pettis, G. S., and Loria, R. 2010. What does it take to be a plant pathogen: genomic insights from Streptomyces species. Antonie van Leeuwenhoek 98:179-194.

Bouchek-Mechiche, K., Gardan, L., Normand, P., and Jouan, B. 2000. DNA relatedness among strains of Streptomyces pathogenic to potato in France: description of three new species, S. europaeiscabiei sp. nov. and S. stelliscabiei sp. nov. associated with common scab, and $S$. reticuliscabiei sp. nov. associated with netted scab. Int. J. Syst. Evol. Microbiol. 50:91-99.

Bukhalid, R. A., Chung, S. Y., and Loria, R. 1998. necl, a gene conferring a necrogenic phenotype, is conserved in plant-pathogenic Streptomyces spp. and linked to a transposase pseudogene. Mol. Plant-Microbe Interact. 11:960-967.
Bukhalid, R. A., Takeuchi, T., Labeda, D., and Loria, R. 2002. Horizontal transfer of the plant virulence gene, necl, and flanking sequences among genetically distinct Streptomyces strains in the Diastatochromogenes cluster. Appl. Environ. Microbiol. 68:738-744.

Cao, Z., Khodakaramian, G., Arakawa, K., and Kinashi, H. 2012. Isolation of borrelidin as a phytotoxic compound from a potato pathogenic Streptomyces strain. Biosci. Biotechnol. Biochem. 76:353-357.

Chamberlain, K., and Crawford, D. L. 2000. Thatch biodegradation and antifungal activities of two lignocellulolytic Streptomyces strains in laboratory cultures and in golf green turfgrass. Can. J. Microbiol. 46:550-558.

Clark, C. A., Chen, C., Ward-Rainey, N., and Pettis, G. S. 1998. Diversity within Streptomyces ipomoeae based on inhibitory interactions, rep-PCR, and plasmid profiles. Phytopathology 88:1179-1186.

Dees, M. W., Sletten, A., and Hermansen, A. 2013. Isolation and characterization of Streptomyces species from potato common scab lesions in Norway. Plant Pathol. 62:217-225

Dees, M. W., and Wanner, L. A. 2012. In search of better management of potato common scab. Potato Res. 55:249-268.

Doroghazi, J. R., and Buckley, D. H. 2010. Widespread homologous recombination within and between Streptomyces species. ISME J. 4:1136-1143.

Euzeby, J. P. 2016. Genus Streptomyces. List of Prokaryotic Names with Standing in Nomenclature. Int. J. Syst. Bacteriol. http://www.bacterio.net/streptomyces.html

Faucher, E., Paradis, E., Goyer, C., Hodge, N. C., Hogue, R., Stall, R. E., and Beaulieu, C. 1995. Characterization of streptomycetes causing deep-pitted scab of potato in Quebec, Canada. Int. J. Syst. Bacteriol. 45:222-225.

Faucher, E., Savard, T., and Beaulieu, C. 1992. Characterization of actinomycetes isolated from common scab lesions on potato tubers. Can. J. Plant Pathol. 14: 197-202.

Fitch, W. M. 1971. Toward defining the course of evolution: minimum change for a specific tree topology. Syst. Zool. 20:406-416.

Flores-Gonzalez, R., Velasco, I., and Montes, F. 2008. Detection and characterization of Streptomyces causing potato common scab in Western Europe. Plant Pathol. 57: $162-169$

Fyans, J. K., Bown, L., and Bignell, D. R. D. 2016. Isolation and characterization of plant-pathogenic Streptomyces species associated with common scabinfected potato tubers in Newfoundland. Phytopathology 106:123-131.

Guo, Y., Zheng, W., Rong, X., and Huang, Y. 2008. A multilocus phylogeny of the Streptomyces griseus $16 \mathrm{~S}$ rRNA gene clade: use of multilocus sequence analysis for streptomycete systematics. Int. J. Syst. Evol. Microbiol. 58:149-159.

Healy, F. G., Bukhalid, R. A., and Loria, R. 1999. Characterization of an Insertion Sequence Element Associated with Genetically Diverse Plant Pathogenic Streptomyces spp. J. Bacteriol. 181:1562-1568

Hillis, D. M., and Bull, J. J. 1993. An empirical test of bootstrapping as a method for assessing confidence in phylogenetic analysis. Syst. Biol. 42 182-192.

Huguet-Tapia, J. C., Bignell, D. R., and Loria, R. 2014. Characterization of the Integration and Modular Excision of the Integrative Conjugative Element PAISt in Streptomyces turgidiscabies Car8. PLoS One 9:e99345.

Huguet-Tapia, J. C., Lefebure, T., Badger, J. H., Guan, D., Pettis, G. S., Stanhope, M. J., and Loria, R. 2016. Genome Content and Phylogenomics Reveal both Ancestral and Lateral Evolutionary Pathways in Plant-Pathogenic Streptomyces Species. Appl. Environ. Microbiol. 82:2146-2155.

Jordaan, E., and van der Waals, J. E. 2016. Streptomyces species associated with common scab lesions of potatoes in South Africa. Eur. J. Plant Pathol. 144: 631-643.

Kers, J. A., Cameron, K. D., Joshi, M. V., Bukhalid, R. A., Morello, J. E., Wach, M. J., et al. 2005. A large, mobile pathogenicity island confers plant pathogenicity on Streptomyces species. Mol. Microbiol. 55:1025-1033.

Kim, B. J., Kim, C. J., Chun, J., Koh, Y. H., Lee, S. H., Hyun, J. W., et al. 2004 Phylogenetic analysis of the genera Streptomyces and Kitasatospora based on partial RNA polymerase $\beta$-subunit gene (rpoB) sequences. Int. J. Syst. Evol. Microbiol. 54:593-598.

Labeda, D. P. 2011. Multilocus sequence analysis of phytopathogenic species of the genus Streptomyces. Int. J. Syst. Evol. Microbiol. 61:2525-2531.

Lambert, D. H., and Loria, R. 1989a. Streptomyces acidiscabies sp. nov. Int. J. Syst. Bacteriol. 39:393-396

Lapaz, M. I., Verdier, E., and Pianzzola, M. J. 2012. First report regarding potato scab caused by Streptomyces acidiscabies in Uruguay. Plant Dis. 96:1064.

Laskaris, P., Sekine, T., and Wellington, E. M. 2012. Diversity analysis of Streptomycetes and associated phosphotranspherase genes in soil. PLoS One 7:e35756.

Leiminger, J., Frank, M., Wenk, C., Poschenrieder, G., Kellermann, A., and Schwarzfischer, A. 2013. Distribution and characterization of Streptomyces species causing potato common scab in Germany. Plant Pathol. 62:611-23.

Loria, R., Bukhalid, R. A., Creath, R. A., Leiner, R. H., Olivier, M., and Steffens, J. C. 1995. Differential production of thaxtomins by pathogenic Streptomyces species in vitro. Phytopathology 85:537-541.

Loria, R., Bukhalid, R. A., Fry, B. A., and King, R. R. 1997. Plant pathogenicity in the genus Streptomyces. Plant Dis. 81:836-846.

Loria, R., Clark, C. A., Bukhalrd, R. A., and Fry, B. A. 2010. Gram positive bacteria. Pages 236-249 in: Laboratory Guide for Identification of Plant Pathogenic Bacteria. N. W. Schaad, J. B. Jones, and W. Chun, eds. American Phytopathological Society, St. Paul, MN. 
Loria, R., Kers, J., and Joshi, M. 2006. Evolution of plant pathogenicity in Streptomyces. Annu. Rev. Phytopathol. 44:469-487.

Louws, F. J., Fulbright, D. W., Stephens, C. T., and De Bruijn, F. J. 1995. Differentiation of genomic structure by rep-PCR fingerprinting to rapidly classify Xanthomonas campestris pv. vesicatoria. Phytopathology 85:528-536.

MGAP and Mercado Modelo. 2011. Situación del cultivo de la papa. Mercado Modelo, Observatorio Granjero, Montevideo, Uruguay. http://www.mercadomodelo. net/c/document_library/get_file?uuid=42d591df-f681-4f2c-82b9-cbe388ac3af3\& groupId $=10157$

Miyajima, K., Tanaka, F., Takeuchi, T., and Kuninaga, S. 1998. Streptomyces turgidiscabies sp. nov. Int. J. Syst. Bacteriol. 48:495-502.

Pánková, I., Sedláková, V., Sedlák, P., and Krejzar, V. 2012. The occurrence of plant pathogenic Streptomyces spp. in potato-growing regions in central Europe. Am. J. Potato Res. 89:207-215.

Park, D. H., Kim, J. S., Kwon, S. W., Wilson, C., Yu, Y. M., Hur, J. H., and Lim, C. K. 2003. Streptomyces luridiscabiei sp. nov., Streptomyces puniciscabiei $\mathrm{sp}$. nov. and Streptomyces niveiscabiei sp. nov., which cause potato common scab disease in Korea. Int. J. Syst. Evol. Microbiol. 53:2049-2054.

Saitou, N., and Nei, M. 1987. The neighbor-joining method: A new method for reconstructing phylogenetic trees. Mol. Biol. Evol. 4:406-425.

Sambrook, J., and Russell, D. W. 2001. Molecular Cloning: A Laboratory Manual, 3rd Ed. Cold Spring Harbor Laboratory Press, Cold Spring Harbor, NY.

Seemann, T. 2014. Prokka: Rapid prokaryotic genome annotation. Bioinformatics 30:2068-2069.

Seipke, R. F., and Loria, R. 2008. Streptomyces scabies 87-22 possesses a functional tomatinase. J. Bacteriol. 190:7684-7692.
Shirling, E. B., and Gottlieb, D. 1966. Methods for characterization of Streptomyces species. Int. J. Syst. Bacteriol. 16:313-340.

Siri, M. I., Sanabria, A., and Pianzzola, M. J. 2011. Genetic diversity and aggressiveness of Ralstonia solanacearum strains causing bacterial wilt of potato in Uruguay. Plant Dis. 95:1292-1301.

Song, J., Lee, S. C., Kang, J. W., Baek, H. J., and Suh, J. W. 2004. Phylogenetic analysis of Streptomyces spp. isolated from potato scab lesions in Korea on the basis of $16 \mathrm{~S}$ rRNA gene and $16 \mathrm{~S}-23 \mathrm{~S}$ rDNA internally transcribed spacer sequences. Int. J. Syst. Evol. Microbiol. 54:203-209.

St-Onge, R., Goyer, C., Coffin, R., and Filion, M. 2008. Genetic diversity of Streptomyces spp. causing common scab of potato in eastern Canada. Syst. Appl. Microbiol. 31:474-484.

Tamura, K., Peterson, D., Peterson, N., Stecher, G., Nei, M., and Kumar, S. 2011. MEGA5: molecular evolutionary genetics analysis using maximum likelihood, evolutionary distance, and maximum parsimony methods. Mol. Biol. Evol. 28: 2731-2739.

Wanner, L. A. 2004. Field isolates of Streptomyces differ in pathogenicity and virulence on radish. Plant Dis. 88:785-796.

Wanner, L. A. 2006. A survey of genetic variation in Streptomyces isolates causing potato common scab in the United States. Phytopathology 96: 1363-1371.

Wanner, L. A. 2009. A patchwork of Streptomyces species isolated from potato common scab lesions in North America. Am. J. Potato Res. 86:247-264.

Zhang, Y., Bignell, D. R., Zuo, R., Fan, Q., Huguet-Tapia, J. C., Ding, Y., and Loria, R. 2016. Promiscuous Pathogenicity Islands and Phylogeny of Pathogenic Streptomyces spp. Mol. Plant-Microbe Interact. 29:640-650. 